\title{
When History Teaching Turns into Parrhesia: The Case of Italian Colonial Crimes
}

\section{Giovanna Leone}

\section{INTRODUCTION}

The aim of this chapter was to highlight the importance and the consequentiality of a specific kind of history education that happens when teachers decide to openly narrate to their students the crimes committed by previous generations of their own group-crimes so far kept silenced and literally denied in the general social discourse. By applying to this teaching the discussion of Foucault (1983) on truth and social discourse, we propose to single it out from other kinds of teaching designed for learning about controversial issues (Leone 2012; Leone and Sarrica 2014). We think, in fact, that this kind of history education has to be distinguished from other kinds of difficult teaching on sensitive issues. Many times history teachers may be confronted with classrooms that could be divided by their own idea of what happened in the past. To quote only a couple of examples of this situation, imagine to be a teacher trying to explain Northern Ireland struggles in Dublin or in London (Barton and McCully 2012); or imagine to teach to your pupils the apparently innocent story of native Americans feeding starving newcomers disembarked from the Mayflower, being aware that this episode could be accounted for as an act of generosity or as the first moment of

\footnotetext{
G. Leone $(\square)$

Sapienza University of Rome, Rome, Italy

e-mail: giovanna.leone@uniromal.it

(C) The Author(s) 2017

C. Psaltis et al. (eds.), History Education and Conflict Transformation, DOI 10.1007/978-3-319-54681-0_6
} 
a process leading to a terrible genocide (Kurtiş et al. 2010). But some other times, history teachers break down a silence about the facts that are not disputed, yet ignored by the large majority of society. Imagine, to quote an example of this other kind of issues, to teach to your French students that Vichy is a city historically known not only for its mineral water (Campbell 2006); or imagine, in a much more dangerous situation, to be a courageous teacher trying to convey to your Turk students the reasons why some historians call the mass killings of Armenians as genocide (Bilali 2013) Namely, according to Foucault's categorization of different kinds of social discourse aimed to convey truth, we propose that historical teaching that addresses not controversial past, but socially denied historical facts may be regarded as a specific case of parrhesia: a kind of social discourse that, addressing troubling issues, "chooses frankness instead of persuasion, truth instead of falseness or silence, (...) the moral duty instead of self-interest or moral apathy" (Foucault 2001, p. 19).

In the first part of the chapter, specificities of this kind of history education will be discussed. More in particular, theoretical expectancies on effects of this strategy of history education will be related to the discussion of Foucault on empowering consequences of parrhesia. In spite of the risk of aggressive or defensive reactions of listeners, parrbesia speaks, in fact, without fear a relevant yet inconvenient truth that, if eventually understood and accepted, may give to its receivers a better grasp on some important reasons accounting for the current features of their own lives.

Moreover, the consequences of this kind of historical education, which frankly unveils the past in-group wrongdoings to students, will be related to the socio-emotional model of needs of victims and perpetrators after the end of a massive social violence (Nadler and Shnabel 2008; Shnabel and Nadler 2015).

Finally, specificities of history education when it becomes a parrhesiastic communication will be understood taking into account how social denial may disempower historical awareness of descendants of perpetrators about relevant facts happened in their in-group past, facts that could allow them to better understand their current in-group and intergroup relations. Here, the concept of knowledge of historical facts has to be linked with the concept of historical thinking (Seixas and Peck 2004), which refers to the abilities school history teaching should provide students with, in order to enable them to approach historical narratives 
critically. Seixas and Peck (2004) distinguish six main elements composing this ability of historical thinking: significance, epistemology and evidence, continuity and change, progress and decline, empathy and moral judgment, and historical agency (Seixas and Peck 2004). Although obviously relying on all these elements in order to be effective, the use of parrhesia when teaching historical wrongdoings of the in-group covered up by a literal social denial (Cohen 2001) addresses in a specific way the dimensions linked to empathy and moral judgment. It has to be stressed that, in this description of Seixas and Peck (2004), empathy is evoked not as a psychological construct, yet as an ability to perspective taking that is historically based. It means that, although trying to "imagine" ourselves in the position of older generations when facing difficult choices, this kind of empathy is not based on "presentism," i.e., a cognitive short cut assuming that all people react in a similar way under different historical and cultural situations. On the contrary, this perspective taking is based "on a rich base of information about the fundamental structures and processes of everyday life during those (past) times" (Seixas and Peck 2004, p. 115), making it clear for students feeling empathy with past generations of the in-group that there are basic differences and changes between their life and life of their ancestors. Being empathic and aware of anachronistic abuses of imposing present-day moral standards to past situation, however, does not imply the impossibility to morally judge on past crimes. In fact, "exactly as with the problem of historical empathy, our ability to make moral judgment in history requires that we entertain the notion of an historically transcendent human commonality" (Seixas and Peck 2004, p. 115). Speaking fearlessly about moral transgressions committed by the in-group and then denied in the following social discourse, parrhesia specifically address this capability to recognize this urge to morally judge the past inherited by previous generations, without nourishing a relativism that disallows any condemnation, also when it is largely deserved.

In the second part of the chapter, results of a case study on contemporary history teaching about colonial crimes committed by the Italian Army during the Ethiopia invasion (1935-1936) will be presented, in order to observe how conveying this knowledge, although referring to remote facts, may produce considerable effects on present-day young Italians. This study explores how such a kind of historical teaching, narrating in-group misdeeds formerly denied in the social discourse, may help young descendants of perpetrators to better understand their 
current intergroup relations. According to the classic theoretical position of Ortega y Gasset (1930), in fact, historical knowledge referred to the group in which one happens to be born may be seen as a precious tool to improve awareness of one's own "historical pre-existence," i.e. of the past situations that account for present-day constraints in intergroup relationships. In this sense, when they help to explain current social conflicts some historical facts, although referred to remote past, may nevertheless be felt as "psychologically contemporary" (Lewin 1943).

The case study presented in this chapter could be seen as additional evidence that colonial crimes, similarly to all other contents eliciting controversial reactions of receivers, belong to this particular category of "psychologically contemporary" historical events. In fact, both the psychological past and the psychological future are simultaneous parts of the social perception of the situation existing at a given time. This classic theoretical remark of Lewin (1943) may be easily adapted to our times, when we read in newspapers that Islamic terrorists claim that their victims are "Crusaders," or when we quote recent comments of former London's Mayor and now Minister of Foreign Affairs of the UK, Boris Johnson, to Obama's advice that the UK is better off by staying in the European Union. Replying to this political speech of the US President, Boris Johnson attributed this opinion to Barak Obama's "ancestral dislike" for Britain as a result of his "part-Kenyan" heritage that made him hostile to his former colonizers. Apart from controversies stirred by these somehow appalling comments, the Mayor of London's political argument is a very good example of how much social perception of current international relations may be influenced by the psychological contemporaneity of the ancient ghosts of colonial violence (Volpato and Licata $2010)$.

Moreover, the exemplum given by the research discussed in the second part of this chapter explores risks yet great opportunities offered by the breaking of a long-lasting social silence on the past wrongdoings of a social group. The complete denial of colonial crimes committed by the Italian Army during the invasion of Ethiopia, in fact, makes the contemporary historical education on these facts deeply different from any other kinds of difficult history teaching. This case study, therefore, is presented not to discuss the specifics of Italian history, but to better understand what happens in situations when social silence is widespread across all other sources of information available to young generations and history teaching is the only way to frankly speak to them about the moral indignities of their group. 
In this chapter, the idea that in these situations history education may turn into parrhesia is advanced. It is proposed that, when all the multiple sources contributing to build a social representation of history (family reminiscing and conversations, literature and arts, movies, media narratives, etc.) deny for a long time that historical events accounting for moral indignities of the in-group occurred, only historians may offer to young descendants of perpetrators a precious occasion to cope with this difficult knowledge of their in-group past.

However, an issue at stake for studying more in depth this specific kind of history education refers to the consequences theoretically expected when history teaching breaks such a long-lasting and widespread denial. If we consider as prominent the psychological need for a positive social identity (Tajfel 1982), avoidance of inconvenient facts could be expected as the best way of coping with a troubling past and each frank narrative may be seen, on the contrary, as a threat. According to this theoretical frame, psychological consequences of a frank history teaching about socially denied crimes are expected to be mainly negative. But if we understand acknowledgment of past responsibilities as a first unavoidable step for a real intergroup reconciliation (Vollhardt et al. 2014), then presenting descendants of perpetrators with a frank and truthful narrative of in-group wrongdoings may be seen on the contrary as the best choice to cope with this difficult past, since the lack of knowledge of past in-group responsibilities may be expected to threaten the harmony of current intergroup relations. According to this other theoretical frame, even if first psychological reactions in front of a clear narrative of in-group crimes could be expected to be ambivalent or fully negative, in the long run the breaking of an unrealistic denial could be expected to produce overall positive consequences for receivers, enabling them to better understand the history of their group.

This chapter deals with the issue of reactions and consequences of this specific kind of history education both theoretically and empirically. Although theoretical expectations and empirical evidence aspects are obviously intertwined, for clarity's sake theoretical points will be previously discussed, starting from Michel Foucault's considerations on the evolution of truth-speaking strategies used in classic Greek culturestrategies that could be seen as the root of modern attitudes toward the dilemma between facing or avoiding historical narratives conveying inconvenient historical indignities to young generations. 


\section{Michel Foucault on Parrhesia}

In his problematization of different kinds of truth-speaking - that he saw as social activities to be studied not from an epistemological, but from a pragmatic point of view-Foucault proposed to categorize them according to their effects on receivers. More particularly, he singled out a specific kind of them that he named parrbesia, tracing back an old concept firstly proposed by classic Greek philosophers. According to its classic Greek root, the word parrhesia describes a kind of truth-speaking that, by openly and fearlessly conveying a disturbing knowledge, implies a risk for those telling it (parrhesiastes). The parrhesiastes is a person who, being free to choose whether to do it or not, speaks a difficult truth in order to accomplish a sense of moral duty toward receivers. Moreover, the parrhesiastes chooses to speak frankly the truth regardless of any risk to himself. The parrhesiastes speaks so frankly and fearlessly the truth, because he appreciates advantages of this choice both for him and for his receivers. Referring to himself, communication being in Foucault's point of view an influential social activity, the parrbesiastes chooses to openly speak the truth in order to safeguard harmony between his words and his acts. Referring to receivers, Foucault maintains that the dangerous choice of truth-speaking challenges yet empowers them. In fact, such an uneasy truth may, if accepted, make receivers able to cope with some important evidence that they would have preferred to ignore.

Foucault argues that it is precisely its empowering effect that makes parrhesia different from other kinds of troubling communication, as, for instance, the aggressive ones. However, being effects of communication linked not only to source's intention, but also to receiver's capacity and will to understand, parrhesia may be better defined as a "communication game", leading to positive effects for receivers only when a cooperation of both speakers and listeners successfully occurs. Apart from reactions of receivers, however, parrhesia turns out to be always an expression of protection of the parrhesiastes, reinforcing their personal harmony between their words and their social actions. Regardless of its final outcomes, therefore, parrhesia is always a way of taking care of oneself, an action of cura sui. Taking all together these different aspects, parrhesia may be regarded therefore as a specific kind of education, since the authority of the parrhesiastes does not come from power or status, but only from his free moral choice-encouraging receivers to take care of themselves and to treat receivers of their own communication in a similar way (Foucault 1983). 
In this chapter, I propose to apply Foucault's discussion on the utility of singling out parrhesia as a specific kind of truth-speaking, to describe the specific social activity by which history teachers decide to uncover for their students a moral indignity committed in the past by their groupa moral indignity so far kept silent and even denied in the general social discourse. Assuming the pragmatic point of view that frames Foucault's studies, we may consider history teaching that breaks down social silence on past in-group crimes as a specific communicative choice, inserted into the wider set of social and psychological processes eventually leading to intergroup reconciliation (Nadler et al. 2008). More precisely, it could be argued that the factual evidence provided by this specific kind of history teaching, provided when this same evidence is lacking in any other kind of social discourse, is essential for descendants of past perpetrators to fully acknowledge past historical responsibilities of their group (Vollhardt et al. 2014).

According to the theoretical model on different needs of perpetrators and victims after a massive intergroup violence (Nadler and Shnabel 2008; Shnabel and Nadler 2015), acknowledgment is foreseen as a difficult yet unavoidable step toward a sound intergroup reconciliation. When violence ends, in fact, perpetrators need to be reinserted in their community, avoiding the exclusion due to their wrongdoings. Victims, on the contrary, need to recover control on their own lives, after being helpless and unable to defend themselves. When the group of perpetrators fully accepts responsibilities for hurting their victims, it opens the door for meeting the needs of both victims and perpetrators, as described in the Nadler and Shnabel model (2008).

In spite of its clear-cut description of different needs of victims and perpetrators, however, this socio-emotional model of reconciliation does not address the issue of how long it could take for groups to arrive to face their past lack of morality-if perpetrators-or their lack of agency-if victims (Cajani and Leone 2015). Sometimes, the search for historical truth is straightforwardly linked to reconciliation processes: given, for instance, the famous example of the Truth and Reconciliation Committees in South Africa, where, at the presence of the local community and of its authorities, truthful narratives of violence were overtly negotiated between victims and perpetrators (Gibson 2006).

Apart from this specific cultural situation, however, an immediate and overt acknowledgment of violence rarely occurs in perpetrators' communication. In particular when victims are too weak or socially isolated, 
their voice is seldom heard. In these more frequent situations, silence on violence could take place for a long time in the social arena and go down the generations. It implies that the needs described by the Nadler and Shnabel model (2008; Shnabel and Nadler 2015), as directly associated with victims and perpetrators, may go down the generations too and affect the social and psychological needs of their descendants.

If we take into consideration both the model proposed by Nadler and Shnabel (2008; Shnabel and Nadler 2015) and the evidence of the possibility that often many years are needed for atrocities to be overtly recognized and officially narrated to descendants of perpetrators' group (Leach et al. 2013), we can agree on the idea that the same needs foreseen for perpetrators and victims may go down the generations, to influence descendants of victims and perpetrators too (Bilewicz and Jaworska 2013; Leone 2012).

It is clear that, when a long time elapses from the end of the violence to its full acknowledgment by perpetrators, the dilemma between avoidance and coping with this difficult truth begins to affect not only the current social discourse but also the historical teaching. At this point, we may ask ourselves whether it is necessary to draw a dividing line between history education that breaks down a long-lasting social silence on past violence enacted by the group and other kinds of difficult teaching on sensitive issues.

\section{Parrhesia And Controversial Historical Issues in the Classroom}

Past historical crimes of the group in which one happens to be born are one out of many controversial issues that could emerge during classroom discussions. However, unlike other sensitive issues (see, for instance, Goldberg 2013; Kello 2015; King 2009; Barton and McCully 2012), history teachers cannot skip or avoid them when narrating to students these periods of the past of their group. Apart from sensitiveness that every competent teacher could have to show when addressing difficult topics (Zembylas and Kambani 2012), in fact, history teachers are expected to inform their students about the more important facts that happened in their group story, since only this learning may give to these adults-to-be a real mastery about their "historical pre-existence" (Ortega y Gasset 1930), steering their future participation to the democratic life of their community. Without knowing relevant past events of one's 
own community, in fact, it is neither possible to judge on contemporary issues, nor to understand contemporary intergroup relations. Generally speaking, this makes intergroup violence a specific topic of history teaching (Sen and Wagner 2005) and, more particularly, teaching on past in-group crimes an essential social activity to foster effective democratic participation in the future life of students.

On the other hand, immediately after the end of violence perpetrators, together with other protagonists of violence such as victims or apathetic bystanders, often use silence among former foes as the first implicit communication concerning the past events. In the first moments after the violence settlement, in fact, silence may appear as a way to restore a sense of "normality" in everyday life. It enhances initial viable local life and allows perpetrators, apathetic bystanders and victims to continue to live side by side (Eastmond and Selimovic 2012).

However, this choice for silence could be more or less common among the multiple sources of information about the past of their own group that are available to young people, ranging from informal settings, such as family narratives, to media communication, literature, or fiction. An analysis of the Italian movies produced after WW2 could provide a striking example of it. Immediately after the end of the war, while silence and avoidance were often used in current social exchanges in order to avoid the high risks of a civil war between those who had adhered to Fascism and who had supported the resistance, the Italian neo-realistic cinema helped nevertheless to convey a representation of humiliation and moral blunting of the Italian people, thanks to movies directed by Rossellini and De Sica (De Caro 2014). However, in the majority of cases the solution of avoiding any open communication concerning violent past does not last, neither can it be enough to cope with violence's aftermaths. As time goes by, in fact, silence instead of being seen as a first viable solution becomes threatening and effortful.

Nevertheless, in some specific cultural situations, silence is not a transient solution. In these unhappy social situations, in fact, as time goes by, silence on past violence cannot be broken. Historians are forbidden to study this period of the in-group past, leaders are not referring to it when commenting on their decisions, and also more informal communication (such as family conversations, or artistic performances, or books, movies, or other fictional narratives) seems to ignore what happened. In these social situations, the transient silence immediately following the end of violence has turned into the highly detrimental states of social 
denial. Referring only to the narratives of perpetrators, denial may occur at different degrees, as a refusal: to admit the historical reality of violent facts (literal denial); to recognize the moral responsibility of perpetrators for these facts (interpretive denial); or to assume the practical consequences of acknowledging one's own responsibility for past violence (implicatory denial) (Cohen 2001).

There is no need to invoke obscure conspiracies, since many aspects account for the "banality" of the well-known phenomenon of social denials. As a matter of fact, we have already quoted some examples in previous pages, since we may often appreciate this phenomenon today in various contexts: the literal denial of the Armenian genocide (Hovannisian 1998; Bilali 2013); the covering up of French collaboration with Nazi occupation (Campbell 2006); the social amnesia about the Italian colonial crimes perpetrated during the occupation of Ethiopia (Leone and Sarrica 2012); the rhetoric of official discourses on Thanksgiving day, when US presidents avoid to remember the role of native Americans in episodes commemorated by this special day (Kurtiş et al. 2010), to quote only a few. Instead of well-organized manipulation, historical denials dominant in many social situations are often simply the result of "a gradual seepage of knowledge down some collective black hole" (Cohen 2001, p. 13). In these social situations, reconciliation is therefore linked to every intelligent effort performed by the members of the social group of former perpetrators to oppose such an easygoing and generalized seepage, choosing to narrate violence to younger generations instead of letting it disappear down some "black holes."

The choice to break down the social denial originates from a keen understanding of their detrimental consequences for perpetrators' descendants. With literal or interpretive denial, knowledge itself available to descendants of perpetrators is at stake-either because facts themselves are not recognized (literal) or because they are acknowledged, but their interpretation as violent acts is challenged (interpretive), as when violence is claimed to be a kind of self-defense, or the only way to prevent further escalations. Finally, with implicatory denial, what is denied or minimized are "the psychological, political, or moral implications that conventionally follow" (Cohen 2001:8) the knowledge of serious facts, linked to one's own group responsibilities for past atrocities and suffering.

We propose to call "parrhesia" only the history education that breaks down a literal denial so widespread across social sources of information 
and so long-lasting in time, to make history teachers the only possible parrhesiastes among all those who convey to young people a representation of their own historical past. Taken into account all the serious consequences of social denial, it is easy to grasp that it is not possible to challenge either interpretive or implicatory denial, when the mere knowledge of facts is not socially available. It allows us to better understand why the historical teaching that turns into parrhesia, although difficult and risky, may be also regarded as a meaningful empowerment for those who receive at last clear information about past historical indignities of their group.

\section{Empirical Evidence of the Impact of Parrhesia}

However, a basic requirement for this empowerment to be reached is the capacity of students to successfully cope with negative emotions, arising from the difficult historical truth that teachers decide to unveil. To make this point, we will take as an example a research on the case study of Italian university students' reactions to a clear historical description of Italian colonial crimes, formerly silenced and denied in current social discourse. The present-day European collective memories on colonialism, in fact, allow us to find many insightful examples of the different kinds of social denials (Cohen 2001). Sometimes it is possible to observe implicatory denials related to the difficulty of adopting political decisions that take into account the economic consequences of long-lasting exploitation of resources of colonized countries. At other times, an interpretive denial may be observed, when descendants of colonizers are still representing the colonial past of their countries to have been a kind of civilization instead than a systematic exploitation of other groups, implying structural and even direct violence (Galtung and Höivik 1971). In the case study of Italian colonial crimes against Ethiopians, victims having not gained enough power to impose on the research agenda the study of the history of violence they have suffered, until recent years a silence on these facts has been observed in history textbooks (Leone and Mastrovito 2010; Cajani 2013). This lack of historical information, amended only in the most recent manuals, is part of a wider social denial that, for more than seventy years, did not acknowledge these facts to have been proved as true. Moreover, a historical myth replaced factual knowledge, describing Italian soldiers as good fellows, unable of any kind of cruelty (Del Boca 2005). Due to the widespread 
intergenerational silence and the long-lasting social denial, when finally narrated in present-day textbooks, these historical facts-although historically well proven-may sound therefore surprising for young readers. In fact, in spite of recent advances in history teaching, researchers have found that these facts are generally ignored by Italian people, especially younger ones (Pivato 2007). Furthermore, an in-depth textual analysis of the recent Italian history textbooks including this information on past colonial war crimes against Ethiopians has shown that these historical facts are conveyed sometimes in a clear and detailed way, but sometimes in a more evasive one (Leone and Mastrovito 2010).

According to theoretical assumptions previously discussed, only clear historical narratives about these past war crimes can be defined as a kind of parrhesia, since only these texts accept the risk of evoking strong negative reactions from readers. On the contrary, evasive historical textbooks seem to pursue, although in a less open way, the same avoiding aims of previous social denial.

To better understand reactions and consequences of these two different strategies of history education, speaking more or less frankly on past in-group misconduct, an empirical study was organized (Leone and Sarrica 2014). This study explores, through a quasi-experimental procedure, the effects of two different kinds of text addressed to young Italian students, which convey either in a parrhesiastic or in an evasive way the war crimes that happened during the Italian invasion of Ethiopia (1935-1936).

Researchers explored the reactions of 67 Italian university students (average age: 23.51 ) who read two online versions (parrhesiastic vs. evasive) of a same historical text on crimes committed by the Italian Army during the colonial invasion of Ethiopia (1935-1936). This historical text was inserted in a self-administered questionnaire on social representation of Italian colonial past. Questionnaire controlled for previous knowledge of participants on these crimes and asked to self-assess emotions associated with Italian colonial past both before reading the text and again after reading it. The two bogus texts were built referring to the textbooks that are currently used in history teaching and are addressed to Italian high school students. Starting from the same text, the crimes committed against the Ethiopian group were described in a clear way in the parrhesia condition (e.g., saying that the Italian Army used poisonous gases formally forbidden by the Geneva protocol of 1925 during air strikes) or in a less open way in the evasive condition (e.g., saying only that the Italian Army used "unconventional weapons" during 
air strikes). Each participant was covertly videotaped when sitting alone in a room filling in the questionnaire and reading the text. This setting allowed to attribute directly observed first reactions to the reading and not to the actual presence of other people during the fulfillment of experimental tasks. Results were elaborated using statistical comparisons for quantitative data of the questionnaire and qualitative comparison of coding of first reactions during the text reading observed by three independent judges. Quantitative results of the questionnaire showed that as expected, in spite of recent changes in Italian history textbooks, all participants were ignorant about these past war crimes of their in-group. Referring to emotions that participants associated with the Italian colonialism, a statistical comparison of differences between self-assessed emotions scored before and after the information conveyed by the historical text showed that reading the parrhesiastic text affected experienced emotion more than the evasive text. Participants' identification with the ingroup showed no significant interactions with the narrative's effects.

The original mix of paper-and-pencil tools and direct observations allowed to better grasp how the consequences of frank narratives differ from those of evasive ones. Interestingly, first reactions expressed during the reading were different in the two experimental conditions. They were covertly videotaped and coded according to the Facial Action System Coding (FACS) by three independent coders. Before debriefing participants were fully informed of all procedural details, in order to make them able to give or deny their consent to the elaboration of their data and videotapes. No one refused to be included in the elaboration.

A frame-by-frame analysis of videotapes of participants reading the historical text on Italian crimes allowed to grasp micro-expressions shown by their faces while reading the text and to code them according to the FACS. According to Ekman and colleagues, micro-expressions immediately following the exposure to a relevant stimulus are seven: surprise, fear, anger, happiness, disgust, sadness, and contempt. Together with these micro-expressions, faces closely scrutinized may show signs of mental activities: as, for instance, a frowning expression. These facial signs occurring together with micro-expressions are interpreted thanks to them. For instance, a frowning activity, occurring with a micro-expression of surprise, may suggest that the stimulus is difficult to grasp and arises doubts in the mind of the observed person. In spite of the fact that cultural norms on emotional expressions may amplify or reduce these movements of the facial muscles, being largely involuntary, these first 
facial expressions subsequent to relevant stimuli proved to be universal across cultures (Ekman et al. 2013).

This new kind of analysis, made possible by technological advances in videotaping, is based on the idea of Darwin (1965) that the expression of emotions is innate both for man and animals, since inherited as a natural reaction guiding our first efforts to cope with relevant stimuli. For instance, when a stimulus is important, new, and startling, eyelids are so wide-opened that white of the eye is showing above and below. This micro-expression of surprise seems to facilitate a closer look to this unexpected stimulus. In the expression of disgust, both upper and lower lips are raised and nose is wrinkled: This is the expression you make when you smell something bad or take a look on a very dirty room. It is easy to observe how the micro-expression of disgust resembles the first stages of the action of throwing up, when the body rejects a harmful food. Interestingly, these first micro-expressions are common to man and animals, corroborating Darwin's idea of a slow evolution of mankind from other animal species.

However, among the seven facial emotions designated by Ekman and colleagues in their groundbreaking research, only a first reaction is uniquely shown by man, i.e., contempt. While disgust may be expressed for all stimuli-provoking negative sensitive reactions (when seen, smelled, touched, etc.), contempt is shown on the contrary only to express a selfdistancing from the behavior of another human being when it seriously deviates from commonly accepted moral norms.

It is not possible to discuss at length on this important remark provided by Ekman et al. (2013) about the insightful evidence originating from their research. I would only comment that their observations on the unique role of contempt among the first human reactions to emotion-provoking stimuli seem to ask again, starting from the new evidence offered by modern technologies, the old philosophical question about the wonders of "the moral within" man, seen in the famous quote of Kant as sublime and difficult to explain as the "starry heavens." In this chapter, it should be underlined that only participants assigned to the experimental condition of reading the parrhesiastic historical text showed a first reaction of contempt. Moreover, when self-assessing their own emotions associated with Italian colonialism, participants assigned to the parrhesia condition scored higher in all emotions, but not when selfassessing guilt (Leone and Sarrica 2014). 
Different effects following evasive historical teaching or parrhesia could be grasped if we consider jointly micro-expressions of contempt showed while reading a historical text breaking down the social denial of in-group crimes on the one hand, and changes of emotions on Italian colonialism, self-assessed before and after reading this text, on the other hand. Only parrhesia, in fact, seems to enable young descendants of perpetrators to take a critical distance from the historical responsibilities of previous generations: immediately expressing an innate reaction of self-distancing (contempt) and recognizing through self-aware emotion of shame the need to repair the moral image of the Italian in-group (Allpress et al. 2014). On the contrary, guilt, which could be felt by these young participants born many years after these historical facts only associating their own responsibilities to those of previous generations (Branscombe and Doosje 2004), is not significantly affected by the parrhesiastic historical narrative.

\section{Conclusion}

Concluding these brief notes on situations when historical education turns into parrhesia, I think that it is important to pay attention to the differences between emotional reactions of participants described in the study that we used as an example of this field of research (Leone and Sarrica 2014). I propose that, all results taken together, clearer information provided in the parrhesia condition allowed participants to better regulate their emotional reactions (Frijda 1986), especially their selfconscious or moral emotions (Lewis 2008). The exemplum given in the research described in this chapter shows how these emotions may be seen not only as a barrier (Bar-Tal and Halperin 2013) yet, if well regulated, as a motivational resource (Frijda 1986) to get to know a formerly hidden aspect of one's own historical past.

Of course, not all historical sensitive issues require a parrhesiastic narrative, but those breaking a long-lasting social denial of past in-group faults. Only in this last case, in fact, psychological processes linked to first emotional reactions become crucial, since there is not a consolidated and widespread historical culture framing this knowledge, silenced since teacher's intervention. In such a situation, literal social denial (Cohen 2001) on past moral indignities of the group produces a lack of historical knowledge that makes parrhesiastic teaching a risky yet unavoidable communication move, since there is a need to break a social silence 
disempowering young generations' capacity to cope with the troubled past of the in-group they are born in. More in particular, referring to the dimensions that teaching should provide, in order to enable students to confront historical narratives critically (Seixas and Peck 2004), a parrhesiastic account of past in-group wrongdoings formerly silenced in the social discourse address at a same time historical perspective taking and empathic attitude toward the past, as well as capability to morally judge previous generations. On the one hand, straightforwardly filling a gap on basic information about relevant processes occurred in the past, a parrhesiastic teaching on socially denied in-group crimes allow its receivers to understand the history of their group referring firmly to factual evidence instead than to a delusive and fictional version of it. On the other hand, rooted in this rich base of truthful information, a moral judgment may follow, finally acknowledging ethic responsibilities of former generations.

In such a situation, the choice of using parrhesia (Foucault 1983) as a strategy of history education can allow perpetrators' descendants to cope at the same time with the two opposed aims of protecting the state symbology (Liu et al. 2014) and of advancing intergroup reconciliation processes (Nadler and Shnabel 2008; Shnabel and Nadler 2015).

Summing it up, it seems that the concept of parrhesia, i.e., of a specific kind of the truth-speaking communications generally used in the social discourse (Foucault 1983), could be fruitfully used also to better understand social and psychological processes linked to the case of a historical teaching that uncovers a formerly denied truth referred to the national past - a truth that could threaten both the social and moral identity of its receivers (Allpress et al. 2014), but that could also help young students to better understand the current historical position of their country.

In particular, moral group-based emotions expressed by students when told about these negative facts could be used as important methodological cues, in order to describe the main effects of these difficult historical narratives. On the one hand, according to a well-consolidated field of research (Frijda 1986), moral group-based emotions are predictive of the consequentiality of learning activities - since only important issues are able to provoke emotional reactions. On the other hand, moral group-based emotions may play also a relevant self-regulatory role, by inhibiting the well-proven tendency to in-group favoritism (Shepherd et al. 2013). 
However, to better appreciate the different emotional reactions of students exposed either to controversial and difficult history teaching or to parrhesia, much more research is needed. These differences between students' reactions could be highly consequential for theoretical reasons-shifting our attention from defensive consequences of self-categorization processes to the intriguing issue of the self-regulatory role of group-based emotions. Certainly, reactions studied in this kind of studies are mostly referred to students in their young adulthood. Theoretical reasons could account to that, since in democracies young adults are expected to take their own place in the public forum to gradually substitute old generations. It is up to young adults, in fact, to decide to eventually continue or to change the political orientations of public actions, and this difficult choice could not be taken if a clear knowledge of facts happened during their "historical pre-existence" (Ortega y Gasset 1930 ) is lacking. But also reactions of participants belonging to other age groups could be extremely important to know and therefore more research is needed in this specific direction.

Moreover, and more importantly, discussing on these differences could also advance our understanding of psychological processes in the educational field. In particular, I would like to propose that studies on concrete cases when all other sources of information are silent and only history teachers break down a long-lasting social denial of past crimes of the group could be highly influential, since for younger generations of perpetrators' groups moral reparation is a basic social and psychological need as well as for their ancestors (Nadler and Shnabel 2008; Shnabel and Nadler 2015; Bilewicz and Jaworska 2013; Leone 2012). For educational purposes, understanding psychological reactions which regulate group-based emotions of young students, when their teachers make a clear knowledge of moral faults of in-group history finally available for them, can be a key element helping to explain how intergroup relations may not only stay hostile for a long time, but may also change and flourish again when generations change.

\section{REFERENCES}

Allpress, J. A., Brown, R., Giner-Sorolla, R., Deonna, J. A., \& Teroni, F. (2014). Two faces of group-based shame: Moral shame and image shame differentially predict positive and negative orientations to in-group 
wrongdoing. Personality and Social Psychology Bulletin, 40(10), 1270-1284. doi:10.1177/0146167214540724.

Bar-Tal, D., \& Halperin, E. (2013). The nature of socio-psychological barriers to peaceful conflict resolution and ways to overcome them. Conflict of Communication Online, 12(2), 1-16.

Barton, K. C., \& McCully, A. W. (2012). Trying to "see things differently": Northern Ireland students' struggle to understand alternative historical perspectives. Theory \& Research in Social Education, 40(4), 371-408.

Bilewicz, M., \& Jaworska, M. (2013). Reconciliation through the righteous: The narratives of heroic helpers as a fulfillment of emotional needs in PolishJewish intergroup contact. Journal of Social Issues, 69(1), 162-179.

Bilali, R. (2013). National narrative and social psychological influences in Turks' denial of the mass killings of Armenians as genocide. Journal of Social Issues, $69(1), 16-33$.

Branscombe, N. R., \& Doosje, B. (2004). Collective guilt: International perspectives. Cambridge: Cambridge University Press.

Cajani, L. (2013). The image of Italian colonialism in Italian history Textbooks for secondary schools. Journal of Educational Media, Memory, and Society, $5(1), 72-89$.

Cajani, L., \& Leone, G. (2015) How long it takes to face collective responsibilities: The case study of public awareness on crimes of Italian colonialism. In: Social representation of history: Social psychological and historical approaches to their antecedents, evolution, and role in influencing identities and intergroup relations, Pécs, Hungary, April 9-10th, 2015.

Campbell, J. (2006). Vichy, Vichy, and a plaque to remember. French Studies Bulletin, 27(98), 2-5.

Cohen, S. (2001). States of Denial: Knowing about atrocities and suffering. Cambridge: Polity Press.

Darwin, C. R. (1965). The expression of emotions in man and animals. Chicago: University of Chicago Press. (Original edition, 1872).

De Caro, G. (2014). Rifondare gli italiani? Il cinema del Neorealismo Il cinema del Neorealismo (Building Italians anew? Neorealism cinema). Milano: Jaca Book.

Del Boca, A. (2005). Italiani, brava gente? Un mito duro a morive (Italians, good fellows? A myth that dies hard). Vicenza: Neri Pozza.

Eastmond, M., \& Selimovic, J. M. (2012). Silence as possibility in postwar everyday life. International Journal of Transitional Justice, ijs026, 6(3): 502-524. first published online October 12, 2012 doi:10.1093/ijtj/ijs026.

Ekman, P., Friesen, W. V., \& Ellsworth, P. (2013). Emotion in the human face: Guidelines for research and an integration of findings. Burlington: Elsevier.

Frijda, N. H. (1986). The emotions. London, England: Cambridge University Press. 
Foucault, M. (1983). Discourse and truth: The problematization of Parrhesia. Six lectures given by Michel Foucault at the University of California at Berkeley [also published in 2001 under the title Fearless Speech. Los Angeles: Semiotexte].

Galtung, J., \& Höivik, T. (1971). Structural and direct violence: A note on operationalization. Journal of Peace Research, 8(1), 73-76.

Gibson, J. L. (2006). The contributions of truth to reconciliation: Lessons from South Africa. Journal of Conflict Resolution, 50(3), 409-432.

Goldberg, T. (2013). "It's in My Veins": identity and disciplinary practice in students' discussions of a historical issue. Theory \& Research in Social Education, $41(1), 33-64$.

Hovannisian, R. G. (1998). Remembrance and denial: The case of the Armenian genocide. Detroit: Wayne State University Press.

Kello, K. (2015). Sensitive and controversial issues in the classroom: Teaching history in a divided society. Teachers and Teaching, 1-19.

King, J. T. (2009). Teaching and learning about controversial issues: Lessons from Northern Ireland. Theory \& Research in Social Education, 37(2), 215-246.

Kurtiş, T., Adams, G., \& Yellow Bird, M. (2010). Generosity or genocide? Identity implications of silence in American Thanksgiving commemorations. Memory, 18(2), 208-224.

Leach, C. W., Zeineddine, F. B., \& Čehajić-Clancy, S. (2013). Moral immemorial: The rarity of self-criticism for previous generations' genocide or mass violence. Journal of Social Issues, 69(1), 34-53.

Leone, G. (2012). May clarity about in-group crimes be a better choice, when narrating the story of past war to perpetrators descendants? In: 11th International Conference on Social Representations. Social Representations in Changing Societies. Evora, Portugal, June 25-28, 2012.

Leone, G., \& Mastrovito, T. (2010). Learning about our shameful past: A sociopsychological analysis of present-day historical narratives of Italian colonial wars. International Journal of Conflict and Violence, 4(1), 11-27.

Leone, G., \& Sarrica, M. (2012). When ownership hurts: Remembering the ingroup wrongdoings after a long lasting collective amnesia. Human Affairs, $22(4), 603-612$.

Leone, G., Sarrica, M. (2014). Making room for negative emotions about the national past: An explorative study of effects of parrhesia on Italian colonial crimes. International Journal of Intercultural Relations, 1-13. doi:10.1016/j. ijintrel.2014.08.008.

Lewin, K. (1943). Defining the 'field at a given time'. Psychological Review, $50(3), 292-310$.

Lewis, M. (2008). Self-conscious emotions: Embarrassment, pride, shame, and guilt. In M. Lewis, J. Haviland-Jones, \& L. Feldman Barrett (Eds.), Handbook of emotions (3rd ed., pp. 742-756). New York: Guilford Press. 
Liu, J. H., Onar, N. F., \& Woodward, M. W. (2014). Symbologies, technologies, and identities: Critical junctures theory and the multi-layered nation-state. International Journal of Intercultural Relations, 43, 2-12.

Nadler, A., Malloy, T., \& Fisher, J. D. (Eds.). (2008). Social psychology of intergroup reconciliation: From violent conflict to peaceful co-existence. New York: Oxford University Press.

Nadler, A., \& Shnabel, N. (2008). Instrumental and socioemotional paths to intergroup reconciliation and the needs-based model of socioemotional reconciliation. In A. Nadler, T. E. Malloy, \& J. D. Fisher (Eds.), The social psychology of intergroup reconciliation (pp. 37-56). New York: Oxford University Press.

Ortega y Gasset, J. (1930). La rebelión de las masas [The Revolt of the Masses]. Madrid.

Pivato, S. (2007). Vuoti di memoria: usi e abusi della storia nella vita pubblica italiana [Memory lapses: Uses and misuses of history in Italian public life]. Roma-Bari: Laterza.

Seixas, P., \& Peck, C. (2004). Teaching historical thinking. In A. Sears \& I. Wright (Eds.), Challenges and prospects for Canadian social studies (pp. 109-117). Vancouver: Pacific Educational Press.

Sen, R., \& Wagner, W. (2005). History, emotions and hetero-referential representations in inter-group conflict: The example of Hindu-Muslim relations in India. Papers on Social Representations, 14, 2.1-2.23.

Shepherd, L., Spears, R., \& Manstead, A. S. (2013). 'This will bring shame on our nation': The role of anticipated group-based emotions on collective action. Journal of Experimental Social Psychology, 49(1), 42-57.

Shnabel, N., \& Nadler, A. (2015). The role of agency and morality in reconciliation processes the perspective of the needs-based model. Current Directions in Psychological Science, 24(6), 477-483.

Tajfel, H. (ed) (1982). Social identity and intergroup relations. New York: Cambridge University Press.

Vollhardt, J. R., Mazur, L. B., \& Lemahieu, M. (2014). Acknowledgment after mass violence: Effects on psychological well-being and intergroup relations. Group Processes \& Intergroup Relations, 17(3), 306-323. doi:10.1177/1368430213517270.

Volpato, C., \& Licata, L. (2010). Collective Memories of Colonial Violence. Special issue of International Journal of Conflict and Violence, 4(1): 4-10.

Zembylas, M., \& Kambani, F. (2012). The teaching of controversial issues during elementary-level history instruction: Greek-Cypriot teachers' perceptions and emotions. Theory \& Research in Social Education, 40(2), 107-133. 


\section{Author Biography}

Giovanna Leone is Associate Professor of Social Psychology at Sapienza University of Rome, Italy, where she teaches Social Psychology and Communication, Political Psychology and Community Psychology. Full member of several national and international academic associations. MC Member of Italy in the COST European action IS1205 "Social psychological dynamics of historical representations in the enlarged European Union". Former coordinator of the Ethics Committee of AIP (Association of Italian Psychologists). Her main research interests include: social and collective aspects of autobiographical memory; ambivalent effects of over-helping, as observed in multicultural classrooms; relationships between changes of historical narratives on past intergroup violence and reconciliation. She published papers on Lecture Notes in Computer Science, International Journal of Conflict and Violence, International Journal of Intercultural Relations, Cognitive Processing, Journal of Language and Politics, Papers in Social Representations, Qualitative Research in Psychology, Human Affairs. She contributed to the first and second edition of the Cambridge Handbook of Sociocultural Psychology.

Open Access This chapter is licensed under the terms of the Creative Commons Attribution 4.0 International License (http://creativecommons.org/licenses/ by $/ 4.0 /$ ), which permits use, sharing, adaptation, distribution and reproduction in any medium or format, as long as you give appropriate credit to the original author(s) and the source, provide a link to the Creative Commons license and indicate if changes were made.

The images or other third party material in this chapter are included in the chapter's Creative Commons license, unless indicated otherwise in a credit line to the material. If material is not included in the chapter's Creative Commons license and your intended use is not permitted by statutory regulation or exceeds the permitted use, you will need to obtain permission directly from the copyright holder.

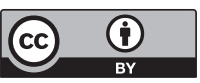

